\title{
A NOVEL SINTERING-DISSOLUTION PROCESS FOR MANUFACTURING AI FOAMS
}

\author{
Y.Y. Zhao and D.X. Sun \\ Materials Science and Engineering, Department of Engineering, The University of Liverpool, \\ Brownlow Hill, Liverpool L69 3GH, UK
}

(Received June 27, 2000)

(Accepted July 6, 2000)

Keywords: Sintering; Dissolution; Aluminium; Foams

\section{$\underline{\text { Introduction }}$}

Al foams have found increasing applications in a wide range of structural and functional products, due to their exceptional mechanical, thermal, acoustic, electrical and chemical properties [1-3]. Al foam structures have densities only fractions of that of a solid structure and therefore have high specific strength and stiffness. They also have excellent properties for impact energy, vibration and sound absorption. Examples of their applications include lightweight panels for building and transport against buckling and impact, non-flammable ceiling and wall panels for thermal and sound insulation. Open cell foams can also be used as heat exchangers, filters and catalyst carriers. The applications of $\mathrm{Al}$ foams on a large scale are likely to be in the automotive industry with an aim to improve the vehicle crashworthiness and thus passenger safety.

There currently exist a wide range of manufacturing methods [1-3], which can generally be grouped into five categories according to the forms of the precursory $\mathrm{Al}$ and the types of the pore-forming agents, namely melt-gas injection, melt-foaming agent, powder-foaming agent, investment casting and melt infiltration. However, the $\mathrm{Al}$ foams produced by these methods are either too expensive due to the high production costs or too poor in quality due to poor controllability in pore structure and porosity. As a consequence, the commercial applications of $\mathrm{Al}$ foam components are still limited. With a rapidly increasing demand for high quality $\mathrm{Al}$ foams, there has been a growing need for developing cost effective manufacture technologies.

This paper describes a new sintering-dissolution process (SDP) for manufacturing net-shape, open-cell $\mathrm{Al}$ foams, characterises the porosity, microstructure and compressive properties of the foams produced under a range of SDP conditions, and discusses the capabilities of SDP.

\section{Experimental Procedure}

SDP consists of the mixing, compacting, sintering and dissolution stages as shown schematically in Fig. 1. The raw materials are $\mathrm{Al}$ and $\mathrm{NaCl}$ powders. The particle sizes of the $\mathrm{Al}$ powder are not critical but generally required to be smaller than $1 \mathrm{~mm}$. The particle sizes of the $\mathrm{NaCl}$ powder depend on the intended pore sizes of the final foam. The $\mathrm{Al}$ powder is first mixed thoroughly with the $\mathrm{NaCl}$ powder at a pre-specified volume or weight ratio. The resultant $\mathrm{Al} / \mathrm{NaCl}$ powder mixture is compacted into a net-shape preform under an appropriate pressure. The preform is then sintered at a temperature either 


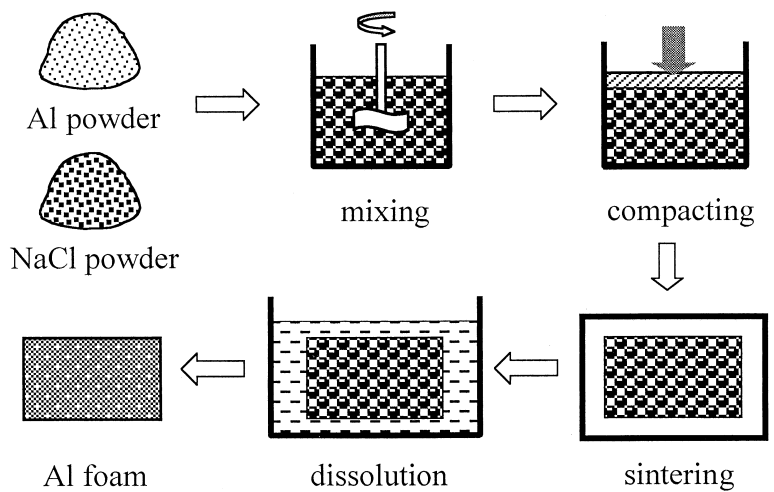

Figure 1. Schematic of the sintering-dissolution process for manufacturing $\mathrm{Al}$ foams.

above or below the melting point of $\mathrm{Al}\left(660^{\circ} \mathrm{C}\right)$ but far below that of $\mathrm{NaCl}\left(801^{\circ} \mathrm{C}\right)$. After the $\mathrm{Al}$ in the preform forms a well-bonded networked structure, the preform is cooled to room temperature. The imbedded $\mathrm{NaCl}$ particles are finally dissolved in water, leaving behind an open cell $\mathrm{Al}$ foam with the same chemical composition as that of the original Al powder.

In manufacturing the $\mathrm{Al}$ foam specimens, a commercial purity gas atomised $\mathrm{Al}$ powder with particle sizes below $450 \mu \mathrm{m}$ and a commercial purity $\mathrm{NaCl}$ powder with nodular particles and particle sizes of 300-1000 $\mu \mathrm{m}$ were used. The two powders were mixed thoroughly at different weight ratios with the $\mathrm{Al}$ weight fractions in the range $0.20-0.75$. The mixtures were compacted into preforms in steel moulds using a hydraulic press with a pressure typically of $200 \mathrm{MPa}$. The preforms, together with the moulds, were sintered in an electric furnace at $680^{\circ} \mathrm{C}$ for $180 \mathrm{~min}$ and were then allowed to cool to the room temperature. The sintered specimens were removed from the moulds and placed into a warm, running water stream for $45 \mathrm{~min}$ to dissolve the $\mathrm{NaCl}$ particles embedded in the $\mathrm{Al}$ matrices.

For each specimen, the weights of the initial $\mathrm{Al}$ powder, the $\mathrm{NaCl}$ powder, a sample cut from the sintered $\mathrm{Al} / \mathrm{NaCl}$ preform, and the resultant $\mathrm{Al}$ foam were measured using a balance to an accuracy of $0.01 \mathrm{~g}$. The size of the foam was also measured to determine its volume and hence its density. The fraction of the residual $\mathrm{NaCl}$ in the $\mathrm{Al}$ foam with respect to the total $\mathrm{NaCl}$ in the initial $\mathrm{Al} / \mathrm{NaCl}$ preform, $\varphi$, was determined by:

$$
\varphi=\frac{W_{f}-W_{p} f_{A l}}{W_{p}\left(1-f_{A l}\right)}
$$

where $W_{f}$ and $W_{p}$ are the weights of the $\mathrm{Al}$ foam and the corresponding pre-dissolution $\mathrm{Al} / \mathrm{NaCl}$ preform respectively, and $f_{A l}$ is the $\mathrm{Al}$ weight fraction in the initial $\mathrm{Al} / \mathrm{NaCl}$ powder mixture. In order to give a direct indication of the porosity of the $\mathrm{Al}$ foam, the foam was characterised by relative density, which is the ratio of the density of the foam to that of the bulk Al. Theoretically, the relative density is equivalent to the volume fraction of $\mathrm{Al}$ in the initial $\mathrm{Al} / \mathrm{NaCl}$ preform, if the preform is $100 \%$ dense and all the $\mathrm{NaCl}$ particles in the preform are completely dissolved away in the dissolution stage. The theoretical relative density of the resultant foam, $\rho$, was therefore calculated from the $\mathrm{Al}$ weight fraction in the preform by:

$$
\rho=\frac{f_{A l} \rho_{\mathrm{NaCl}}}{f_{A l} \rho_{\mathrm{NaCl}}+\left(1-f_{A l}\right) \rho_{A l}}
$$

where $\rho_{A l}=2.70 \mathrm{~kg} / \mathrm{m}^{3}$ and $\rho_{\mathrm{NaCl}}=2.17 \mathrm{~kg} / \mathrm{m}^{3}$ are the $\mathrm{Al}$ and $\mathrm{NaCl}$ densities respectively. 


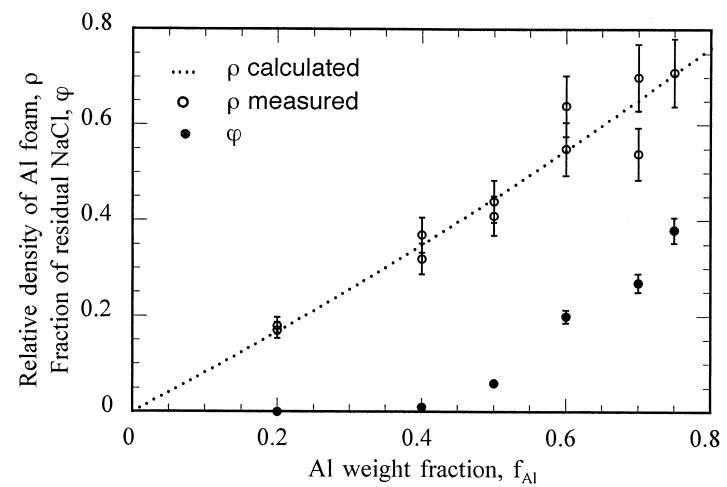

Figure 2. Relationship between relative foam density, fraction of residual $\mathrm{NaCl}$ and $\mathrm{Al}$ weight fraction.

The microstructure of the foam specimens was examined by a Hitachi S-2460N scanning electron microscope (SEM). The compression tests of the specimens were conducted on an Instron 4505 materials testing system at a crosshead speed of $1 \mathrm{~mm} / \mathrm{min}$. The specimens for the compression tests were $20 \mathrm{~mm}$ in diameter and $20 \mathrm{~mm}$ in height.

\section{$\underline{\text { Results and Discussion }}$}

It was demonstrated in the experiments that net-shape $\mathrm{Al}$ foam components can be produced in SDP by either liquid or solid state sintering. In liquid state sintering, the sintering temperature was higher than the melting point of $\mathrm{Al}$. The $\mathrm{Al}$ particles in the $\mathrm{Al} / \mathrm{NaCl}$ preform all melted and became a continuous liquid pool filling up the spaces between the solid $\mathrm{NaCl}$ particles. Because of the poor wetting and the difference in density between liquid $\mathrm{Al}$ and solid $\mathrm{NaCl}$, the molten $\mathrm{Al}$ tended to separate with the $\mathrm{NaCl}$ particles. Without physical confinement, the molten $\mathrm{Al}$ would ooze out from the preform under gravitational and capillary forces. A mould must be used during sintering to maintain the preform geometry. Solid state sintering was conducted without using a mould, because the sintering temperature was lower than the melting point of Al. However, it required a strict control over the processing conditions, such as the physical and chemical characteristics of the Al powder and the sintering environment. Further work is needed to evaluate and compare the benefits of the liquid and solid state sintering approaches.

Fig. 2 shows the variations of the theoretical and measured relative densities of the $\mathrm{Al}$ foam, $\rho$, and the fraction of the residual $\mathrm{NaCl}$ in the $\mathrm{Al}$ foam, $\varphi$, with the $\mathrm{Al}$ weight fraction in the initial $\mathrm{Al} / \mathrm{NaCl}$ powder preform, $f_{A l}$. The theoretical relative density was calculated by equation (2), assuming that the initial $\mathrm{Al} / \mathrm{NaCl}$ preform was $100 \%$ dense and all the $\mathrm{NaCl}$ particles in the subsequently sintered preform was completely dissolved away. In practice, however, there was always some air trapped in the $\mathrm{Al} / \mathrm{NaCl}$ preform during compaction, leading to a lower relative density than the theoretical value. In most cases, the $\mathrm{NaCl}$ particles in the sintered preform could not be dissolved completely. Some $\mathrm{NaCl}$ particles remained in the resultant foam, leading to a higher relative density than the theoretical value. As a consequence, there was often a considerable difference between the calculated and measured relative densities.

The amount of trapped air in an $\mathrm{Al} / \mathrm{NaCl}$ preform is determined by the particle morphology and size of the $\mathrm{Al}$ and $\mathrm{NaCl}$ powders as well as the compacting pressure. Under the current compacting conditions, the effect of trapped air is not significant. The effect of the residual $\mathrm{NaCl}$ in the foam on 


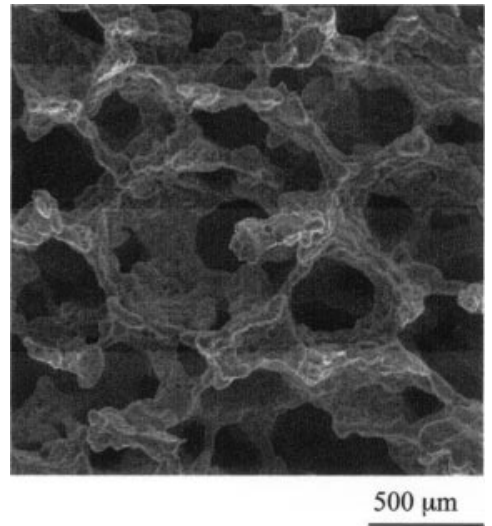

Figure 3. SEM micrograph of a typical Al foam manufactured by SDP.

the relative density of the foam, however, cannot be neglected. A sintered $\mathrm{Al} / \mathrm{NaCl}$ preform can be seen as a composite of $\mathrm{Al}$ matrix with embedded $\mathrm{NaCl}$ particles. With a high volume fraction of $\mathrm{NaCl}$ in the preform, most $\mathrm{NaCl}$ particles are in contact with each other and form a continuous three-dimensional network. Because all the $\mathrm{NaCl}$ particles in the network can be dissolved away by water, there is only small amount of residual $\mathrm{NaCl}$ in the resultant foam. In contrast, with a low volume fraction of $\mathrm{NaCl}$ in the preform some $\mathrm{NaCl}$ particles are enclosed completely by the $\mathrm{Al}$ matrix. These isolated $\mathrm{NaCl}$ particles cannot be dissolved away and remain in the foam. Increasing $\mathrm{Al}$ weight fraction in the $\mathrm{Al} / \mathrm{NaCl}$ preform decreases the $\mathrm{NaCl}$ volume fraction and therefore increases the amount of residual $\mathrm{NaCl}$ in the final $\mathrm{Al}$ foam. Fig. 2 shows that residual $\mathrm{NaCl}$ in the foam was very small when the $\mathrm{Al}$ weight fraction in the preform was below 0.4. When the $\mathrm{Al}$ weight fraction was increased to $0.5,0.6,0.7$ and 0.75 , the fraction of the residual $\mathrm{NaCl}$ in the foam with respect to the total $\mathrm{NaCl}$ in the initial preform increased to $0.06,0.20,0.27$ and 0.38 , respectively. The relative density of the foam with a high $\mathrm{Al}$ weight fraction in the initial preform was therefore expected to be higher than the theoretical value. The measured relative densities of the foams at $\mathrm{Al}$ weight fractions $>0.6$, however, were not always higher than the calculated ones and showed greater variations between individual measurements. This might be because the $\mathrm{Al}$ distributions in the $\mathrm{Al} / \mathrm{NaCl}$ preforms were not uniform and consequently the local $\mathrm{Al}$ weight fractions of the samples were somewhat different from those of the whole specimens from which the samples were cut.

SDP is most suitable for manufacturing $\mathrm{Al}$ foams with relative densities between 0.15 and 0.5 . Within this range, the residual $\mathrm{NaCl}$ in the foam is less than $10 \%$ of the total $\mathrm{NaCl}$ in the initial preform. The relative foam density can be controlled with reasonable accuracy by mixing $\mathrm{Al}$ and $\mathrm{NaCl}$ powders at a pre-specified weight ratio based on equation (2). It is difficult to obtain a relative foam density below 0.15 by SDP, because the $\mathrm{Al}$ particles in the $\mathrm{Al} / \mathrm{NaCl}$ preform with a low $\mathrm{Al}$ weight fraction are largely in isolated patches rather than a continuous network. At a relative density greater than 0.5 , the $\mathrm{Al}$ foam contains more than $10 \%$ of the initial $\mathrm{NaCl}$. The residual $\mathrm{NaCl}$ may result in undesirable corrosion of the Al matrix, degrading the mechanical and chemical properties of the foam.

Fig. 3 shows the SEM micrograph of a typical $\mathrm{Al}$ foam with an Al weight fraction in the initial $\mathrm{Al} / \mathrm{NaCl}$ preform of 0.2 . The foam has a homogeneous structure with open pores and pore sizes in the range 300-1000 $\mu \mathrm{m}$, which represent the particle characteristics of the original $\mathrm{NaCl}$ powder. It is demonstrated that the morphology and sizes of the pores in the foam can be easily controlled by selecting an appropriate $\mathrm{NaCl}$ powder. It is also possible to obtain a purposely tailored distribution of 


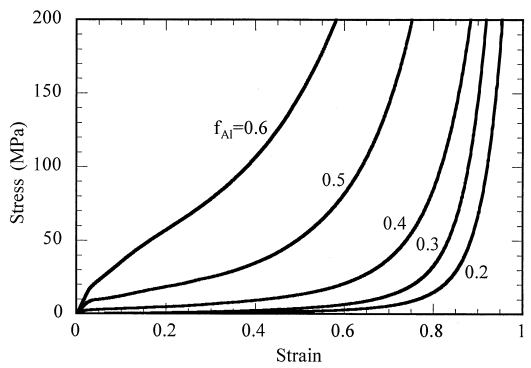

Figure 4. Compressive stress-strain curves of $\mathrm{Al}$ foams with different $\mathrm{Al}$ weight fractions.

pore size or relative density in the foam by using $\mathrm{NaCl}$ powders with different particle size ranges or by varying the local $\mathrm{Al}$ weight fraction in the $\mathrm{Al} / \mathrm{NaCl}$ preform.

Fig. 4 shows the compressive stress-strain curves of the $\mathrm{Al}$ foams with $\mathrm{Al}$ weight fractions in the initial $\mathrm{Al} / \mathrm{NaCl}$ preforms of $0.2,0.3,0.4,0.5$, and 0.6 respectively, which correspond to theoretical relative foam densities of $0.17,0.26,0.35,0.45$ and 0.55 respectively. The curves are generally characterised by an initial elastic response, followed by a deformation "plateau" with a positive slope and finally a transition to densification. The stress at the macroscopic yield point and the subsequent plateau stress at a certain strain increase with increasing relative foam density. One of the characteristics of the foams manufactured by SDP is a very smooth plateau region in the stress-strain curve, as a result of the homogeneously distributed pores having a narrow size range.

The microstructural and mechanical characteristics of the Al foams manufactured by SDP are largely affected by the sintering temperature and time for a certain $\mathrm{NaCl}$ powder and a fixed $\mathrm{Al} / \mathrm{NaCl}$ volume ratio. Sintering temperatures lower than $640^{\circ} \mathrm{C}$ resulted in poor or no bonding between the Al particles, leading to foam disintegration during dissolution or subsequent handling. Temperatures higher than $700^{\circ} \mathrm{C}$, however, increased the flowability of the molten $\mathrm{Al}$, which resulted in partial separation of the $\mathrm{Al} / \mathrm{NaCl}$ mixture and hence a non-uniform distribution of local relative density. Similarly, sintering times shorter than 120 min were not sufficient to ensure good bonding. On the other hand, sintering times longer than 360 min may lead to significant oxidation of the Al matrix or undesirable redistribution of the molten $\mathrm{Al}$ within the preform. The preliminary experimental results suggested that the optimum sintering temperature and time are likely to be in the ranges $640-700^{\circ} \mathrm{C}$ and $120-360 \mathrm{~min}$ respectively.

\section{Summary}

A novel process, SDP, has been developed for manufacturing $\mathrm{Al}$ foams. In $\mathrm{SDP}, \mathrm{Al}$ and $\mathrm{NaCl}$ powders are first mixed at a specified ratio and compacted into a preform. The preform is then sintered below the melting point of $\mathrm{NaCl}$. An $\mathrm{Al}$ foam is obtained after the $\mathrm{NaCl}$ particles embedded in the sintered preform are dissolved away by water. SDP is capable of producing low-cost, net-shape Al foams with controlled pore morphology, size, distribution and porosity. SDP is a very promising technology for manufacturing $\mathrm{Al}$ foams with relative densities in the range $0.15-0.5$ and has great potential for industrial applications.

\section{Acknowledgment}

The work is supported by a grant from the Research Development Fund, The University of Liverpool (RDF2780). We would also like to thank Dr. F. S. Han for the helpful discussions. 


\section{References}

1. L. J. Gibson and M. F. Ashby, Cellular Solids: Structure and Properties, 2nd edn., Cambridge University Press, Cambridge, UK (1997).

2. J. Banhart and H. Eifert, eds., Metal Foams, Verlag MIT Publishing, Bremen (1997).

3. J. Banhart, M. F. Ashby, and N. A. Fleck, eds., Metal Foams and Porous Metal Structures, Verlag MIT Publishing, Bremen (1999). 